\title{
The influence of accounting changes on financial analysts' forecast accuracy and forecasting superiority
}

Citation for published version (APA):

Peek, E. (2000). The influence of accounting changes on financial analysts' forecast accuracy and forecasting superiority. METEOR, Maastricht University School of Business and Economics. METEOR Research Memorandum No. 044 https://doi.org/10.26481/umamet.2000044

Document status and date:

Published: 01/01/2000

DOI:

10.26481/umamet.2000044

Document Version:

Publisher's PDF, also known as Version of record

Please check the document version of this publication:

- A submitted manuscript is the version of the article upon submission and before peer-review. There can be important differences between the submitted version and the official published version of record.

People interested in the research are advised to contact the author for the final version of the publication, or visit the DOI to the publisher's website.

- The final author version and the galley proof are versions of the publication after peer review.

- The final published version features the final layout of the paper including the volume, issue and page numbers.

Link to publication

\footnotetext{
General rights rights.

- You may freely distribute the URL identifying the publication in the public portal. please follow below link for the End User Agreement:

www.umlib.nl/taverne-license

Take down policy

If you believe that this document breaches copyright please contact us at:

repository@maastrichtuniversity.nl

providing details and we will investigate your claim.
}

Copyright and moral rights for the publications made accessible in the public portal are retained by the authors and/or other copyright owners and it is a condition of accessing publications that users recognise and abide by the legal requirements associated with these

- Users may download and print one copy of any publication from the public portal for the purpose of private study or research.

- You may not further distribute the material or use it for any profit-making activity or commercial gain

If the publication is distributed under the terms of Article $25 \mathrm{fa}$ of the Dutch Copyright Act, indicated by the "Taverne" license above, 


\title{
The Influence of Accounting Changes on Financial Analysts' Forecast Accuracy and Forecasting Superiority
}

\author{
ERIK PEEK* \\ Department of Accounting and Auditing \\ Faculty of Economics and Business Administration \\ Maastricht University ${ }^{\dagger}$
}

MARC Working Paper

MARC-WP/3/2000-06

\footnotetext{
${ }^{*}$ The author gratefully acknowledges the contribution of I/B/E/S International Inc. for providing earnings per share forecast data, available through the Institutional Brokers Estimate System. This data has been provided as part of a broad academic program to encourage earnings expectations research. He appreciates helpful comments and suggestions from Ivo Blij, Thomas Buchman, Willem Buijink, Kees Camfferman, Marc De Ceuster, Henri Dekker, Jan Klaassen, Frederick Lindahl, Frank Moers, Stephen Ryan, Ruud Vergoossen and accounting seminar participants at Maastricht University and the Vrije Universiteit Amsterdam.

${ }^{\dagger}$ Address for correspondence: Department of Accounting and Auditing, Faculty of Economics and Business Administration, Maastricht University, P.O. Box 616, 6200 MD Maastricht, The Netherlands. E-mail address: e.peek@berfin.unimaas.nl
} 


\title{
The Influence of Accounting Changes on Financial Analysts' Forecast Accuracy and Forecasting Superiority
}

\begin{abstract}
This study assesses the influence of discretionary accounting changes on financial analysts' individual forecast errors in the Netherlands from 1988 to 1996. It contributes to previous research by examining whether accounting changes (1) influence analysts' earnings forecast accuracy because of the change in the time series of earnings; and (2) change analysts' forecasting superiority relative to mechanical earnings prediction models. The empirical results indicate that changes in accounting procedures significantly affect analysts' forecast accuracy and forecasting superiority.
\end{abstract}

Keywords: Accounting changes, financial analysts, forecast accuracy, forecasting superiority 


\section{INTRODUCTION}

This study investigates whether discretionary accounting changes influence financial analysts' earnings forecasting. A characteristic that distinguishes earnings forecasting from many other decision making processes is the availability of serially correlated historical earnings data. Analysts can use these data to extrapolate earnings trends and forecast future earnings. Accounting changes, which affect the time series of earnings numbers, are therefore expected to influence financial analysts' forecast precision. Prior research has addressed this issue (Brown, 1983; Elliott and Philbrick, 1990).

This study contributes to this line of research by examining whether accounting changes (1) influence analysts' earnings forecast accuracy because of the change in the time series of earnings; and (2) change analysts' forecasting superiority that they have over mechanical earnings prediction models because of the change in the composition of earnings. Accounting changes distort earnings trends but also affect the composition of earnings numbers, which could have an influence on analysts' forecasting performance relative to the forecasting performance of mechanical prediction models. For instance, Bartov and Bodnar (1996) indicate that firms may change accounting procedures to reduce the degree of information asymmetry between managers and investors. From their perspective managers of firms with high information asymmetries have the incentive to choose accounting procedures that are more informative of future performance. Additionally, by adopting new accounting procedures firms could be moving towards an industry norm, which may facilitate interfirm comparisons. Thus, if the newly adopted accounting procedures are either more informative or more in accordance with generally adopted procedures, financial analysts' forecasting superiority over a time series model may increase, even though their forecast accuracy may decrease. 
This paper compares earnings forecast errors in change years and years following a material change in accounting procedures to forecast properties in years prior to a change. The analysis considers a diverse set of accounting changes adopted by firms in the Netherlands from 1988 to 1996. I divide the sample into categories according to whether changes affect earnings before extraordinary items (EBEI), net profit or equity. Contrary to my predictions accounting changes without a material effect on EBEI have a larger negative influence on forecast accuracy, both in change years and in the first year after a change. However, additional tests indicate that forecast accuracy only worsens after the adoption of accounting changes that are accompanied by an increase in my proxy for information asymmetry during the fiscal year. These results suggest that it is not so much the earnings effect as a change in the information environment, that determines forecast accuracy after an accounting change. I further conclude that accounting changes from current cost accounting to historical cost accounting and changes from expensing to capitalisation improve forecast accuracy in years following the change.

In this paper I also develop a simple earnings predictability measure, based on mechanical model prediction errors, and regress it on analysts' consensus forecast errors prior to, during and after change years. The regression analysis reveals that previously disclosed EBEI changes, changes from expensing to capitalisation and changes from current cost accounting to historical cost accounting result in far lower associations between the predictability measure and forecast errors, which suggests that analysts' forecasting superiority increases after these accounting changes. That is, after these changes analysts become not only more accurate but also more superior forecasters in the sense that they are able to correct for a larger fraction of the mechanical model prediction errors than they were able to prior to these changes.

This study differs from prior investigations in several respects. First, this study explicitly 
considers the differential consequences of EBEI changes and equity or net profit changes. Second, earlier research did not explicitly measure earnings predictability and scarcely focused on analysts' forecasting superiority over mechanical prediction models prior to, during and after change years. Third, this study extends US-oriented studies of Brown (1983) and Elliott and Philbrick (1990) to a broader, non-US context. The Dutch accounting environment differs from the US environment by its less strict disclosure requirements. Two distinctive characteristics of the Dutch requirements concerning the adoption of accounting changes may constitute an important determinant of the influence of accounting changes on analysts' forecast accuracy. First, Dutch companies are allowed to present the effect of a change in accounting principles on the financial figures of the preceding year instead of the financial figures of the current year. Second, contrary to disclosure requirements in the United States, Dutch companies are not obliged to restate figures for prior years in the historical summary. Because of these two differences, analysts following a Dutch company access a different information set than those following US companies. Furthermore, this paper considers an accounting change that has not been considered in previous research. It explicitly discusses the influence of changes from current cost accounting to historical cost accounting on forecast accuracy. In the Netherlands many companies have reverted to historical cost accounting in the past decade after a period in which current cost accounting was widely used.

The remainder of this paper is organised as follows. The next section reviews some of the literature on accounting changes and earnings forecasts and describes the hypotheses. Section 3 describes the data selection. The research design and empirical findings are discussed in sections 4 and 5 . Section 6 concludes this paper with some additional comments. 


\section{HYPOTHESES DEVELOPMENT}

\section{(i) The Influence of the Earnings Effect of Accounting Changes}

This study builds partly upon US-studies by Elliott and Philbrick (1990), Brown (1983) and an investigation of Dutch analysts' fixation on accounting figures by Vergoossen (1997). Elliott and Philbrick investigate 612 accounting changes for the years 1976 to 1984 and conclude that in the presence of changes without prior disclosure earnings forecasts in change years are significantly less accurate than forecasts in non-change years. Prior disclosure means that the pending accounting change is publicly announced prior to the earnings announcement date. Vergoossen examines Dutch analysts' investment reports. Results from his study indicate that Dutch financial analysts may ignore changes in accounting policies, especially when the level of disclosure about the change is low.

These studies show that the presence of an accounting change can be expected to impair financial analysts' forecast accuracy as analysts may ignore the impact that such a change has on reported earnings. Therefore, the following hypothesis applies:

$\mathrm{H}_{1}$ : In change years financial analysts' forecast accuracy is worse than forecast accuracy in years prior to an accounting change.

Alternatively, some studies suggest that management uses accruals to manage earnings towards earnings forecasts (Bannister and Newman, 1996; Degeorge et al., 1999), which would improve forecast accuracy due to the presence of accounting changes. Although there is some

evidence of the use of accounting changes for earnings management (see e.g. Sweeney, 1994), I assume that this explanation is less likely, since the use of changes in accounting principles is more costly than other types of accrual manipulation (see Healy, 1985) and the accounting 
change also affects future earnings in a presently unknown direction.

The expectation that accounting changes affect forecast accuracy is based on the assumption that analysts forecast reported earnings as opposed to permanent earnings. This assumption is consistent with the findings of Mest and Plummer (1999), which indicate that analysts forecast persistent earnings over longer forecast horizons, but incorporate transitory earnings components in their short-term forecasts. My study focuses on earnings forecasts of which the forecast horizons are less that one year (short-term forecasts). It is therefore reasonable to assume that these forecasts incorporate transitory earnings components, such as the earnings effect of accounting changes. ${ }^{1}$

Brown (1983) examines forecast errors in the year after the accounting change. His study indicates that earnings forecasts are only slightly affected and that forecasts are less influenced by the change when management provides additional disclosures, such as pro forma adjustments. This study also evaluates forecast accuracy in the years immediately after the accounting change. I expect that the influence of an accounting change on the predictability of future earnings is threefold. First, the change effect constitutes a temporary distortion of earnings trends, which decreases earnings predictability, particularly in the earliest years after the change. Analysts following Dutch companies may have insufficient information to extrapolate earnings trends after the presence of an accounting change, since these companies are not obliged to restate figures for prior years in the historical summary. Second, the newly adopted accounting procedures can either increase or decrease the variability of earnings, which affects the predictive value of reported earnings in subsequent years. That is, an accounting change that leads to a more regular earnings pattern can enhance the usefulness of current earnings in forecasting future earnings. Third, the accounting change can affect the predictive value of other (financial) information. For example, a change from historical 
cost accounting to current cost accounting alters the relationship between market prices and earnings and consequently affects the usefulness of market prices in predicting earnings.

Whereas the influence of the last two factors differs with the type of change, the influence of the first factor on forecast accuracy is generally negative for all types of changes. It is therefore hypothesised that the average effect is a decrease in forecast accuracy in the years immediately after the change.

$\mathrm{H}_{2}$ : In years following the accounting change financial analysts' forecast accuracy is worse than forecast accuracy in years prior to the change, on average.

Hypotheses 1 and 2 both predict that financial analysts do not fully incorporate the change effect in their earnings forecasts, either due to a lack of knowledge or lack of ability. In order to test whether changes in forecast accuracy are attributable to the change effect, I split the sample of accounting changes used in this study into changes with a material effect on earnings before extraordinary items (EBEI changes) and changes with a material effect on net profit or equity (non-EBEI changes). In this paper I define material changes as accounting changes with an effect exceeding five percent of either equity or income. ${ }^{2}$ I expect that in change years EBEI changes have a larger negative effect on forecast accuracy than non-EBEI changes, since forecasts used in this study generally are forecasts of earnings before extraordinary items. I expect that EBEI changes also have a larger negative effect on accuracy than non-EBEI changes in years subsequent to an accounting change, since the earnings effect of EBEI changes causes a larger distortion of earnings trends.

$\mathrm{H}_{3}$ : Accounting changes with a material effect on earnings before extraordinary items (EBEI changes) have a larger negative impact on financial analysts' earnings forecast accuracy, 
both in change years and subsequent years, than accounting changes which affect only net profit or equity materially.

\section{(ii) Prior Disclosure}

In order to investigate the importance of analysts' knowledge relative to ability in adequately incorporating the effect of an accounting change, this study differentiates the data sample according to whether the accounting changes have been disclosed previously. I define prior disclosure as the explicit mention of an accounting change in the annual report of the first year prior to a change year. ${ }^{3}$ In practice the disclosure of a pending accounting change often consists of the announcement that management intends to change the accounting principles underlying next year's annual report and a description of the type of change, without a quantitative specification of the size of the change effect. As noted, earlier studies on financial analysts and accounting changes show that the level of disclosure affects the analysts' ability to cope with the effects of a change (Elliott and Philbrick, 1990; Vergoossen, 1997). I therefore expect that prior disclosure reduces the influence of accounting changes on forecast accuracy.

$\mathrm{H}_{4}$ : Accounting changes that are not disclosed one year prior to the change increase forecast errors relative to previously disclosed accounting changes.

\section{(iii) Expensing to Capitalisation and Current Cost to Historical Cost}

The previous hypotheses focus on the average effect of accounting changes on forecast accuracy. Since different accounting procedures may lead to different levels of earnings predictability, it is useful to additionally focus on the individual effects of particular types of

accounting changes. ${ }^{4}$ In this paper I specifically examine the influence on forecast accuracy of changes from current cost accounting to historical cost accounting (hereafter referred to as 
CCA to HCA changes) and changes from expensing to capitalisation.

I expect that these two types of accounting changes improve analysts' forecast accuracy. The reason for this is that these changes remove unpredictable components from earnings. For instance, earnings based on current cost accounting depend on changes in the value of assets that become known at year end. This means that in predicting earnings financial analysts also have to predict changes in the market value of assets, which makes accurately forecasting more difficult (see Basu et al., 1998). CCA to HCA changes remove the current cost component from earnings, thereby improving earnings predictability. The same argument may hold for changes from expensing to capitalisation. Examples of such changes are changes from expensing to capitalisation of insurance companies' policy acquisition costs or changes from expensing to capitalisation of goodwill. These changes remove the less predictable acquisition costs or goodwill charges from earnings, which is likely to improve analysts' forecast accuracy.

In addition, these two particular types of accounting changes can reduce the variability of reported earnings. This can be explained as follows. Since earnings simply represent the difference between sales and costs, the variance of reported earnings can be defined as a function of the variances and covariance of sales and costs. Hence, the variance of earnings based on current cost accounting exceeds the variance of earnings based on historical cost accounting if the current value of assets exhibits a fairly irregular pattern or if firms do not succeed in regularly adjusting prices to current costs (affecting the covariance of costs and sales). ${ }^{5}$ The effect of changes from expensing to capitalisation on the variability of reported earnings is relatively straightforward. Differences in amount or frequency of goodwill charges or acquisition costs result in the fact that capitalisation and systematic amortisation smoothes reported earnings. ${ }^{6}$ If analysts make use of trend extrapolation in earnings forecasting, a reduction in the variability of earnings would improve analysts' forecast accuracy. This leads 
to the following hypotheses:

$\mathrm{H}_{5 \mathrm{~A}}$ : Financial analysts' forecast accuracy in years after changes from current cost accounting to historical cost accounting is higher than forecast accuracy in years prior to these changes.

$\mathrm{H}_{5 \mathrm{~B}}$ : Financial analysts' forecast accuracy in years after changes from expensing to capitalisation is higher than forecast accuracy in years prior to these changes.

\section{(iv) Analysts' Forecasting Superiority}

The central idea underlying hypotheses $5 \mathrm{~A}$ and $5 \mathrm{~B}$ is that changes from current cost accounting to historical cost accounting and changes from expensing to capitalisation remove unpredictable components from earnings and result in less variable earnings. This should have a positive influence on analysts' earnings forecast accuracy. An implicit assumption in evaluating accounting procedures based on forecast accuracy is that financial reporting aims to provide information that helps analysts in forecasting earnings. However, the objective of financial reporting is probably not so much improving analysts' trend extrapolations as it is improving the information set that analysts use to assess a company's economic performance. An interesting question therefore is whether particular accounting procedures make companies' financial reporting more informative about future company performance or better to understand, to such an extent that analysts' forecast accuracy can increase relative to the accuracy of mechanical prediction models. This section addresses this question.

Early studies of analysts' forecasting abilities indicate that financial analysts have an information advantage over mechanical earnings prediction models (see e.g. Brown et al., 1987; Kross et al., 1990), which makes analysts superior earnings forecasters. The analysts' 
superiority increases as more information becomes available. Brown et al. (1987) define analysts' forecasting superiority (FAFSUP) as the ratio of the squared mechanical model prediction errors $\left(\sigma_{\mathrm{MMFE}}^{2}\right)$ and the squared analyst forecast errors $\left(\sigma_{\mathrm{AFE}}^{2}\right)$ :

$$
\text { FAFSUP }=\frac{\sigma_{\mathrm{MMFE}}^{2}}{\sigma_{\mathrm{AFE}}^{2}}
$$

which decreases towards one when analysts' forecasting advantage over mechanical prediction models decreases.

The companies in my sample that changed from current cost accounting to historical cost accounting generally motivated their change by stating that the newly adopted procedures were more in alignment with nationally and internationally accepted accounting procedures. The companies changing from expensing to capitalisation mostly motivated their change by stating that the newly adopted procedures provided better insights into company performance through improved matching of expenses with benefits. These reported motivations provide a first indication that these two accounting changes could increase analysts' information advantage over mechanical prediction models, either through facilitating interfirm comparisons or through improving the informativeness of financial statements.

When Philips Electronics decided to revert to historical cost accounting in 1992, $\underline{\text { Het }}$

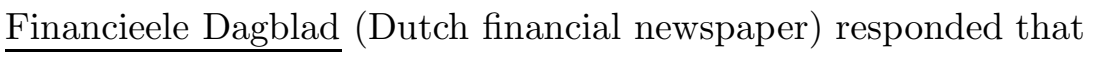

$$
\begin{aligned}
& \text { in accounting technical sense, all this can be regarded as a step backwards. But when } \\
& \text { it all becomes so complex that only a specialist can understand it, then it can be said } \\
& \text { that they have missed their objective. And the less perfect but more understandable } \\
& \text { method used now should be preferred primarily because it increases comparability with } \\
& \text { other companies (quoted in Schattke and Vergoossen, 1996). }
\end{aligned}
$$

Concerns over a reduction in reliability of financial statement information due to the adoption of current cost accounting were expressed by the Financial Accounting Policy Committee of 
the Association for Investment Management and Research (AIMR, 1993, pp. 38-45). These concerns indicate that when companies use current cost accounting, analysts probably find difficulty in understanding and anticipating the current cost component of earnings. I therefore expect that companies' abandonment of current cost accounting makes their financial reports better to understand and more informative (e.g. due to an increase in reliability). This means that after a CCA to HCA change, analysts' information advantage over mechanical prediction models increases, which makes them more superior forecasters, as argued above.

When companies change from expensing to capitalisation of costs, they signal that these costs are an asset to the company. This implies that capitalising and amortising these costs could provide useful information on a company's future profitability. Furthermore, capitalisation and amortisation improves the matching of expenses with benefits, which enhances the informativeness of the company's financial statements. I therefore expect that after changes from expensing to capitalisation analysts' forecast errors decrease relative to the mechanical model prediction errors, resulting in an increase in analysts' forecasting superiority. The following hypothesis applies:

$\mathrm{H}_{6}$ : Analysts' forecasting superiority, defined as the ratio of the squared mechanical model prediction errors and the squared analyst forecast errors, is higher in years after changes from current cost accounting to historical cost accounting and changes from expensing to capitalisation than it is in years prior to these changes. 


\section{SAMPLE SELECTION}

\section{(i) Accounting Changes}

This study restricts the examination of accounting changes to discretionary changes in accounting principles. That is, it excludes changes in accounting estimates and changes in reporting entity. This ensures that definitions of accounting changes of both international and Dutch accounting standards cover the events studied herein and facilitates comparisons with similar studies. This study does not account for adjustments in accounting principles as a result of mergers and acquisitions either, since in these cases non-accounting factors likely distort forecast accuracy.

Legislation and guidelines concerning the adoption of accounting changes in the Netherlands are fairly similar to those of other industrialised countries. Distinctive features of Dutch accounting practices are that almost all of the accounting changes adopted by firms in the Netherlands are discretionary and that firms may choose whether the cumulative effect is reflected in shareholders' equity or in the income statement (as extraordinary income or expense). Furthermore, Dutch guidelines require that companies adjust their financial statement of the preceding year to the newly adopted accounting changes for the purpose of comparison only. Dutch companies are not obliged to restate figures for prior years in the historical summary.

The accounting change data come from the annual reports of 243 companies listed on the Amsterdam Stock Exchange during 1988 to 1996 for one or more years. Out of 1,355 firm-year observations 228 annual reports (16.8 percent) contained at least one accounting change. 125 changes, reported in 102 annual reports (7.5 percent), had an effect of five percent or more on shareholders' equity (hereafter equity) or income. Of these changes 80 (64 percent) affected 
earnings before extraordinary items materially.

The influence on earnings forecast properties of changes with an effect of five percent or more on either income before extraordinary items or net profit/equity is central to this investigation. Table 1 presents the accounting changes that meet this criterion, which shows that these changes are spread over years. I remove firms having changes in two consecutive years from the sample and classify firm-year observations with more than one accounting change in a year as follows. If at least one change affects earnings before extraordinary items materially, I classify these observations as EBEI-changes. I choose the type of change based on the largest change effect.

[Table 1 about here.]

\section{(ii) Earnings Forecasts and Share Prices}

Earnings forecast errors $\left(\mathrm{ERR}_{\text {ist }}\right)$ of firm $i$ and analyst $s$ at time $t$ have the following definitions:

$$
\mathrm{ERR}_{i s t}=\frac{\left|F_{i s t}-E_{i t}\right|}{P_{i t}}
$$

in which $F_{i s t}, E_{i t}$, and $P_{i t}$ denote earnings per share forecast, reported earnings per share and share price of firm $i$ and analyst $s$ at time $t$ respectively.

I/B/E/S International Inc. has provided analysts' individual earnings forecasts from 1987 to 1996. Stock prices come from Datastream. Table 2 shows some descriptive statistics of earnings forecast errors from 1987 to 1996. This study examines analysts' initial one-yearhorizon earnings forecast. The initial one-year-horizon forecast is the first forecast of current year's earnings that an analyst submitted to I/B/E/S after the earnings announcement date 
of the previous fiscal year. Table 2 reports the average number of days between the forecast submission date and the fiscal year end. The mean forecast horizon of the initial earnings forecasts varies from 169 days in the second year after the changes to 183 days in the first year after the changes.

The number of analysts following firms with accounting changes ranges from 1 to 41 . Furthermore, Table 2 shows that the number of analysts following a given firm fluctuates over the time period. The average number of analysts increases from 22 in the second year prior to the change year to 30 in the second year after the change year.

[Table 2 about here.]

\section{ANALYSTS' FORECAST ACCURACY}

\section{(i) Nonparametric Tests}

Part of the research methods used in this study are similar to those of previous studies. When comparing forecast accuracy in years prior to the accounting change with accuracy in the change year or in years after the accounting change, Brown (1983) and Elliott and Philbrick (1990) apply Wilcoxon Signed Rank tests to differences in earnings forecast errors, since nonnormality of their data reduces the validity of parametric $t$-tests. The Wilcoxon Signed Rank test ranks differences between paired absolute forecast errors in ascending order and tests whether the mean rank of negative differences is statistically distinguishable from the mean rank of positive differences. Using the Wilcoxon Signed Rank test requires symmetrically but not necessarily normally distributed observations.

Shapiro-Wilk tests indicate that the data used in this study exhibit a statistically significant departure from normality. ${ }^{7}$ Therefore, I assess the influence of accounting changes 
on forecast errors by using a Wilcoxon matched pairs signed rank test. Matched pairs are $\left(\mathrm{ERR}_{\text {ist }}, \mathrm{ERR}_{\text {ist-1 }}\right),\left(\mathrm{ERR}_{\text {ist }+1}, \mathrm{ERR}_{\text {ist }-1}\right)$ and $\left(\mathrm{ERR}_{\text {ist }+2}, \mathrm{ERR}_{\text {ist-1 }}\right) .{ }^{8} \mathrm{I}$ also determine whether the influence of an accounting change is equal for two independent subsamples, such as EBEI changes and non-EBEI changes, by using a Wilcoxon Rank Sum test. This test ranks the differences between forecast errors of the total sample and tests whether the mean ranks of both subsamples are statistically different..$^{9}$

Comparing forecast accuracy to accuracy in prior years may suffer from the fact that on average accuracy improves through the years. ${ }^{10}$ Therefore, the analysis considers whether the observed changes in forecast accuracy are significantly different from changes in forecast accuracy of a control group. To construct this control sample, I use all available firm-year observations of the firms that did not adopt a material accounting change from 1988 to 1996 and for which both earnings forecasts and share price data were available. For each individual forecast of a given change firm, the control sample contains a forecast which is of a non-change firm of approximately equal size in terms of analyst following in the change year and which is submitted in the same fiscal year. ${ }^{11}$ This forecast is randomly drawn from all available earnings forecasts. I match each sample containing the observations of change firms with 500 control samples, which are randomly drawn from the population of non-change firms, and base all z-statistics on the averages of the 500 rank sums.

\section{(ii) The Influence of the Change Effect and Prior Disclosure}

Panel A of Table 3 shows the results of Wilcoxon tests on the difference between forecast errors in the change year and forecast errors in the year prior to the change. The results do not support hypothesis 1, i.e., that analysts' forecast accuracy is worse in the change year than in prior years. When comparing changes in forecast accuracy in the presence of an 
accounting change with changes in forecast accuracy of the control sample, it appears that accounting changes with a material effect on EBEI have a positive effect on the accuracy of individual earnings forecasts $(\mathrm{z}=-2.20, \mathrm{p}<0.05)$. The influence of non-EBEI accounting changes on forecast accuracy is significantly negative $(\mathrm{z}=1.96, \mathrm{p}<0.05)$.

The impairment of forecast accuracy due to non-EBEI changes continues in the first year after the change $(\mathrm{z}=2.28, \mathrm{p}<0.05)$. The influence of an accounting change on forecast accuracy appears not to persist after the first year subsequent to the change. However, since the percentages of increased forecast errors after EBEI changes and non-EBEI changes are 30.9 percent and 56.2 percent, respectively, the loss of significance in the second year after the change may be due to lower statistical power because of the much smaller sample size. These results do not support hypothesis 2, which predicts that forecast accuracy is worse in the years after an accounting change, and hypothesis 3, which predicts that EBEI changes have a larger negative effect on forecast accuracy than non-EBEI changes.

[Table 3 about here.]

The positive influence of EBEI changes on forecast accuracy indicates that either in presence of an EBEI change management provides analysts with better information than usual or management uses these changes to manipulate earnings towards forecasts. Partitioning the sample of accounting changes on prior disclosure tests the validity of these explanations. In order to fully assess the effect of announcements of an accounting change one year prior to the earnings release date, I divide the sample of changes according to whether or not changes have been disclosed in the annual report one year prior to the earnings release date. Table 4 presents the results. 
[Table 4 about here.]

The positive influence of EBEI changes on forecast accuracy is only significant when these changes have been previously disclosed $(\mathrm{z}=-2.35, \mathrm{p}<0.05)$. This implies that management decided to adopt these changes long before the earnings announcement date of the change year, which makes it less likely that management adopted these changes for the purpose of earnings management. Prior disclosure of non-EBEI changes appears to have a negative effect on forecast accuracy. Panel B of Table 4 shows that non-EBEI changes only impair analysts' earnings forecasts if these changes are previously disclosed $(\mathrm{z}=3.65, \mathrm{p}<0.01)$. These results raise the question as to whether non-EBEI changes are accompanied by the release of worse information than usual and EBEI changes are accompanied by the release of better information than usual. I examine in the next section whether changes in companies' information environment in the years surrounding the accounting change can explain increased forecast accuracy in the presence of EBEI changes and decreased forecast accuracy in the presence of non-EBEI changes.

In sum, I conclude that prior disclosure affects earnings forecast accuracy in change years, but in different directions, depending on the type of change. However, the results are in contrast with the prediction of hypothesis 4, i.e., that accounting changes that are not disclosed one year prior to the change increase forecast errors relative to previously disclosed accounting changes. These results demonstrate that the observed earnings forecast improvements in the presence of certain EBEI changes cannot be attributed to companies using the change to manage earnings towards analysts' predictions, since on average only companies that have disclosed the intention to change in previous year's annual report, show increased forecast accuracy. In the next section I conduct two additional tests to find out why some of the 
results are contrary to my expectations.

\section{(iii) Additional Tests of the Effect of EBEI and Non-EBEI Changes}

The non-parametric Wilcoxon Signed Rank tests that I used in the previous section reduce the influence of the size of forecast accuracy changes by ranking the differences between paired absolute forecast errors, as described above. My objective to use Wilcoxon Signed Rank tests is that the data used in this analysis exhibit a significant departure from normality. An alternative solution to non-normality problems is to use parametric bootstrapped $t$-tests. However, the influence of the size of forecast accuracy changes on bootstrapped $t$-tests is larger than its influence on Wilcoxon Signed Rank tests.

Bootstrapped $t$-statistics on changes in forecast accuracy in the year of an EBEI change and in the first year after an EBEI change confirm my expectations that accuracy worsens after these changes ( $\mathrm{t}=2.48$ and $\mathrm{t}=4.68$, respectively). However, after removing the highest absolute values of changes in forecast errors from my sample, the sign of the $t$-statistics tends to reverse. This suggests that although Wilcoxon tests indicate that the average effect of accounting changes on forecast accuracy is positive, in some instances EBEI changes can have a largely negative effect on forecast accuracy.

The large negative effect of EBEI changes on some of the examined earnings forecasts is in accordance with my prior expectations. However, the question remains why Wilcoxon tests indicate that analysts' forecast accuracy improves after EBEI changes, on average. The fact that some of the empirical results are contrary to expectations, warrants explicit attention for alternative determinants of analysts' forecast accuracy.

To examine whether other determinants of forecast accuracy are driving my results, I 
estimate the following regression equation:

$$
\Delta \mathrm{INDERR}_{i s t}=\gamma_{0}+\gamma_{1} \mathrm{FOLLOW}_{i t}+\gamma_{2} \mathrm{HORIZON}_{i s t}+\gamma_{3} D_{i t}^{\mathrm{STD}}+v_{i t}
$$

in which $\triangle \mathrm{INDERR}_{\text {ist }}$ denotes the signed rank of the change in the individual forecast error of analyst $s$ for company $i$ from the first year prior to the accounting change to year $t$, FOLLOW $_{i t}$ denotes the number of analysts producing earnings forecasts for company $i$ in year $t$, HORIZON ${ }_{i s t}$ denotes the number of days between the forecast date of the forecast of analyst $s$ and the fiscal year end date of company $i$ in year $t . D_{i t}^{\mathrm{STD}}$ is an indicator variable that equals one if the standard deviation of the abnormal stock returns of company $i$ has decreased after the publication of the annual report of year $t$-1. I measure the standard deviation of abnormal stock returns prior (after) to the publication of the annual report of year $t$-1 over a one-year period which ends three months after the fiscal year end of year $t-1$ $($ year $t)$.

The standard deviation deviation of abnormal stock returns proxies for the level of information asymmetry between management and investors, which determines investors' uncertainty about future company performance (see e.g. Krishnaswami and Subramaniam, 1999). I include the variable $D_{i t}^{\mathrm{STD}}$ to examine whether the signed ranks can be explained by changes in the companies' information environment. For example, I test whether forecast accuracy improvements in the presence of EBEI changes can be explained by decreases in the level of information asymmetry after the publication of the annual report of the first year prior to the accounting change. The intercept of equation $3, \gamma_{0}$, measures the extent to which the signed ranks are different from zero after controlling for changes in forecast horizon, analyst following and investor uncertainty. I use a bootstrapping method to estimate equation 3. 
This ensures that the reported bootstrapped $t$-statistic of $\gamma_{0}$ approximates the z-statistic of a Wilcoxon Signed Rank test. Table 5 reports the bootstrapped coefficients and $t$-statistics.

[Table 5 about here.]

Panel A of Table 5 shows that after controlling for changes in forecast horizon and changes in analyst following, signed ranks of forecast accuracy changes in the presence of EBEI changes remain significantly negative $(\mathrm{t}=-2.23, \mathrm{p}<0.05)$, indicating that forecast accuracy improves. However, after including $D_{i t}^{\text {STD }}$ the intercept is not significantly different from zero. The coefficient on $D_{i t}^{\mathrm{STD}}$ is negative and marginally significant $(\mathrm{t}=-1.91, \mathrm{p}<0.10)$, indicating that in the presence of EBEI changes forecast accuracy only improves when the level of information asymmetry has decreased in comparison with information asymmetry in the previous fiscal year. The coefficients for non-EBEI changes indicate that the observed worsening of forecast accuracy in the presence of non-EBEI changes is attributable to increases in the level of information asymmetry. Signed ranks of forecast accuracy changes are significantly positive when the level of information asymmetry has increased $(\mathrm{t}=6.05, \mathrm{p}<0.01)$, but negative when the level of information asymmetry has decreased. Panel B of Table 5 further shows that after controlling for changes in analyst following, forecast horizon and information asymmetry, the signed ranks of forecast accuracy changes in the first year after EBEI changes or non-EBEI changes are not significantly different from zero.

The additional regression analysis thus indicates that changes in forecast accuracy in change years and years after an accounting change can be explained by changes in the level of information asymmetry. The analysis suggests that since non-EBEI changes impair forecast accuracy, these accounting changes are on average part of a deterioration of the company's 
information environment. EBEI changes are on average part of an improvement of the company's information environment.

\section{(iv) Expensing to Capitalisation and Current Cost to Historical Cost}

Since different accounting procedures may lead to different levels of earnings predictability, I also examine the effect of two particular accounting changes. Of all changes documented in this study, changes from expensing to capitalisation of costs and changes from current cost accounting to historical cost accounting (CCA to HCA) are considered to be predictabilityimproving changes, as argued above. Table 6 shows the results of a partition on earnings predictability. In order to test whether changes in forecast accuracy are permanent, I compare forecast errors in the two years after the accounting changes with forecast errors in the first year prior to the changes. The results support hypothesis $5 \mathrm{~A}$, which predicts that CCA to $\mathrm{HCA}$ changes improve forecast accuracy in the years after the accounting change. The difference between CCA to HCA changes and other accounting changes is fairly similar for EBEI changes and non-EBEI changes $(\mathrm{z}=-11.64, \mathrm{p}<0.01$ for EBEI changes, $\mathrm{z}=-2.65, \mathrm{p}<0.01$ for non-EBEI changes). The observed decrease in forecast errors after CCA to HCA changes shows that management's accounting choice can positively affect forecast accuracy.

A significant part of the changes from expense to capitalisation without a material influence on earnings before extraordinary items do not remove an unpredictable component, such as goodwill charges or policy acquisition costs, from earnings. Examples of such accounting changes are the changes from directly charging goodwill to equity to capitalisation of goodwill. When analyzing the effect on forecast accuracy of the removal of an unpredictable component, the focus therefore should be on EBEI changes. Panel A of Table 6 shows the effect of EBEI changes from expense to capitalisation of forecast accuracy in the years after the change. 
Although forecast accuracy increases after these accounting changes $(\mathrm{t}=-2.18, \mathrm{p}<0.05)$, the accuracy improvement is not significantly different from the accuracy improvement after other changes $(\mathrm{t}=0.09)$. Based on these results I reject hypothesis $5 \mathrm{~B}$.

After removing CCA to HCA changes or changes from expensing to capitalisation from the total sample of accounting changes, it appears that the remaining changes decrease forecast accuracy relative to the forecast accuracy of the control group $(\mathrm{z}=2.35, \mathrm{p}<0.05)$. This is in accordance with my expectation that accounting changes worsen forecast accuracy in the years after the change (see hypothesis 2).

[Table 6 about here.]

\section{ANALYSTS' FORECASTING SUPERIORITY}

\section{(i) Regression Analysis}

Hypothesis 6 predicts that financial analysts' forecasting superiority increases after CCA to HCA changes and changes from expensing to capitalisation. Previous studies define analysts' superiority as the ratio of the squared mechanical model prediction errors and the squared analyst forecast errors. If analysts following firm $i$ have the ability to accurately correct for a fraction $\kappa$ of the mechanical model prediction error, their superiority measure will equal:

$$
\text { FAFSUP }=\frac{\sigma_{\mathrm{MMFE}}^{2}}{\sigma_{\mathrm{AFE}}^{2}}=\frac{1}{\left(1-\kappa_{i}\right)^{2}}
$$

in which $\sigma_{\mathrm{MMFE}}^{2}$ denotes the variance of the mechanical model prediction errors and $\sigma_{\mathrm{AFE}}^{2}$ denotes the variance of analysts' forecast errors.

Consider the following regression equation:

$$
\mathrm{AFE}_{i}=\alpha_{0 i}+\alpha_{1 i} \mathrm{MMFE}_{i}+v_{i}
$$


Since analysts following firm $i$ are able to accurately correct for a fraction $\kappa$ of the mechanical model prediction error, the best estimate of $\alpha_{1 i}$ is $1-\kappa$. This illustrates that $\alpha_{1 i}$ decreases with the forecasting superiority of analysts following firm $i$ (FAFSUP, as defined by equation 4). Regressing analysts' forecast errors on mechanical model prediction errors therefore provides insight into analysts' forecasting superiority.

In order to test hypothesis 6 , I estimate a regression equation that is similar to equation 5. This requires developing a measure of the accuracy of mechanical prediction models, hereafter referred to as earnings (un)predictability. Earlier studies of Lys and Soo (1995) and Das et al. (1998) have constructed a composite earnings predictability measure which is based on a stock return model and/or earnings time-series. This paper uses a similar approach. I measure earnings unpredictability as follows. Using all available earnings data between 1987 and 1996 of the firms that made an accounting change during this period, I estimate the following three earnings prediction models: ${ }^{12}$

1. Random walk model:

2. Autoregressive model:

3. $\quad$ Returns model:

$$
\begin{aligned}
& E_{i t}=E_{i t-1}+\epsilon_{i t} \\
& E_{i t}=\phi_{0}+\phi_{1} E_{i t-1}+v_{i t} \\
& E_{i t}=\alpha_{0}+\alpha_{1} R_{i t}+\eta_{i t}
\end{aligned}
$$

in which earnings are scaled by stock prices at the beginning of the fiscal year. Stock returns $\left(R_{i t}\right)$ have the following definition:

$$
R_{i t}=\frac{P_{i t}-P_{i, t-1}}{P_{i, t-1}}
$$

in which $P_{i t}$ denotes the share price of firm $i$ at time $t .{ }^{13}$ The stock returns are computed from nine months prior to the beginning of the fiscal year to three months after the fiscal yearend. The returns model thus measures to what extent the information which is conveyed by share prices in the two years prior to the earnings announcement date, is helpful in predicting earnings. 
The unpredictability measure $\left(\mathrm{UP}_{i t}\right)$ is equal to the sum of the absolute values of (standardised) forecast errors $\epsilon_{i t}, v_{i t}$ and $\eta_{i t}$, that is:

$$
\mathrm{UP}_{i t}=\left(\left|\epsilon_{i t} / \sigma_{\epsilon}\right|+\left|v_{i t} / \sigma_{v}\right|+\left|\eta_{i t} / \sigma_{\eta}\right|\right)
$$

Hence, a high unpredictability score implies that historical (earnings) information is less useful in predicting reported earnings and that mechanical prediction models are less accurate. I choose to equally weigh standardised errors of the three different models because this avoids making arbitrary assumptions about which of these models best reflects analysts forecasting process. Standardisation of the error terms insures that if one of the models estimates worse than the other models, it could not drive the results and conclusions would not be based on the worst model.

Finally, I rank the unpredictability scores in ascending order and transform the ranks to normally distributed rank scores with mean 0 and variance 1 . This solves problems with forecast error outliers in statistical analyses. Since the presence of an accounting change is likely to cause forecast error outliers, these outliers most likely provide valuable information. Using a rank transformation procedure guarantees that the outliers are part of the analysis, but do not drive the results. ${ }^{14}$

In order to test hypothesis 6 , i.e., that analysts' forecasting superiority is higher in years after CCA to HCA changes and changes from expensing to capitalisation than it is in years prior to these changes, I estimate the following equation:

$$
\begin{aligned}
\operatorname{CONSERR}_{i t}= & \beta_{0}+\beta_{1} \mathrm{UP}_{i t}+\beta_{2} \mathrm{FOLLOW}_{i t}+\beta_{3} \mathrm{SIZE}_{i t}+ \\
& +\beta_{4} D_{i t}^{\mathrm{AC}}+\beta_{5} D_{i t}^{\mathrm{AFTER}}+\beta_{6} D_{i t}^{\mathrm{DISC}}+\beta_{7} D_{i t}^{\mathrm{PRED}}+ \\
& +\beta_{8} D_{i t}^{\mathrm{AC}} \mathrm{UP}_{i t}+\beta_{9} D_{i t}^{\mathrm{AFTER}^{\mathrm{PFP}}} \mathrm{UP}_{i t}+
\end{aligned}
$$




$$
+\beta_{10} D_{i t}^{\mathrm{DISC}} \mathrm{UP}_{i t}+\beta_{11} D_{i t}^{\mathrm{PRED}} \mathrm{UP}_{i t}+\varepsilon_{i t}
$$

in which $\mathrm{CONSERR}_{i t}$ denotes the consensus forecast error, that is the average initial oneyear-horizon forecast error. Dummy variable $D_{i t}^{\mathrm{AC}}\left(D_{i t}^{\mathrm{AFTER}}\right)$ equals 1 if firm i makes an accounting change in (before) year t. Dummy variable $D_{i t}^{\text {PRED }}$ equals 1 if firm i has adopted CCA to HCA changes or changes from expensing to capitalisation before year $\mathrm{t}$ and $D_{i t}^{\mathrm{DISC}}$ equals 1 if firm i has disclosed the presence of an accounting change one year prior to the change. $\mathrm{UP}_{i t}$ denotes the unpredictability rank of firm i in year t. FOLLOW $i t$ equals the number of analysts that follows firm i in year $\mathrm{t}, \mathrm{SIZE}_{i t}$ equals the market value of common equity of firm i at the fiscal year-end. These two variables should control for the effect of differences in analyst following and size on forecast accuracy (cf. Das et al., 1998).

I accept hypothesis 6 when the relationship between financial analysts' forecast errors and earnings unpredictability is less pronounced in years after CCA to HCA changes and changes from expensing to capitalisation than it is in years prior to these changes $\left(\beta_{11}<0\right)$. Including $D_{i t}^{\mathrm{AFTER}} \mathrm{UP}$ in the regression equation ensures that $D^{\mathrm{PRED}} \mathrm{UP}$ measures the extent to which the effect on analysts' forecasting superiority of CCA to HCA changes and changes from expensing to capitalisation is different from the effect of all other accounting changes (instead of different from zero). I further include $D_{i t}^{\mathrm{AC}} \mathrm{UP}$ and $D_{i t}^{\mathrm{DISC}} \mathrm{UP}$ to gain insight into the effect of accounting changes on analysts' forecasting superiority in the change year.

One of the assumptions underlying Ordinary Least Squares regressions is that the error terms of a regression are normally distributed. This assumption may not be valid when analysts' forecast errors are the dependent variable, since the forecast errors are absolute values. This may lead to non-normality of the error term distribution. Shapiro-Wilk tests on the residuals of the Ordinary Least Squares regressions in this paper indicate that these residuals 
are non-normally distributed $(\mathrm{W}=0.6973, \mathrm{p}<0.01)$. To overcome some of the problems associated with non-normally distributed error terms, I use the following bootstrapping method. ${ }^{15}$ First, given that the original sample contains $\mathrm{n}$ observations, I obtain 1,000 resamples by sampling with replacement $\mathrm{n}$ observations from the original sample. Second, I estimate b parameters $\beta_{k}^{b}$ for each bootstrap sample k. Finally, the mean and standard error of each parameter can be calculated on the basis of the bootstrap parameter estimates. That is, the bootstrap parameter mean equals $\frac{1}{K} \sum_{k=1}^{K} \beta_{k}^{b}$ and the bootstrap estimate of standard error equals $\left[\frac{1}{K-1} \sum_{k=1}^{K}\left(\beta_{k}^{b}-\frac{1}{K} \sum \beta_{k}^{b}\right)^{2}\right]^{\frac{1}{2}}$, in which $\mathrm{K}=1,000$.

This procedure ensures that the validity of inferences about the parameter estimates is much less dependent on the empirical distribution of the error terms. Furthermore, an advantage of this bootstrapping method is that the method is valid in the presence of heteroskedasticity and that the results of this method can be expected to be fairly similar to those from using a heteroskedasticity-consistent covariance matrix estimator (Davidson and MacKinnon, 1993). ${ }^{16}$

\section{(ii) Analysts' Forecasting Superiority}

Table 7 reports the bootstrap estimates of regressions predicting consensus forecast errors as a function of the unpredictability rank (UP), firms' size (SIZE), analyst following (FOLLOW) and indicator variables denoting different attributes of accounting changes. The objective of this regression analysis is to determine whether the relation between analysts' forecast errors and ex-ante earnings predictability is less pronounced after a firm has adopted more informative accounting procedures. The indicator variables $D^{\mathrm{AC}}, D^{\mathrm{AFTER}}, D^{\mathrm{DISC}}, D^{\mathrm{EBEI}}$ (denoting the presence of EBEI changes), and $D^{\mathrm{PRED}}$ are included in the regressions but not reported in Table 7. 
[Table 7 about here.]

The coefficient of the unpredictability rank (UP) is significantly positive at the 0.01 alpha level $(0.0526, \mathrm{t}=3.06)$. A higher unpredictability score thus implies lower forecast accuracy in the years prior to an accounting change. The results also reveal that the association between earnings predictability and forecast accuracy decreases due to earnings predictability improving changes, i.e. CCA to HCA changes and changes from expensing to capitalisation $(\mathrm{t}=-3.45, \mathrm{p}<0.01)$. This implies that the newly adopted accounting procedures, i.e. historical cost accounting and capitalisation of costs, are more informative than the previously used procedures, which increases analysts' forecasting superiority. When I replace $D^{\mathrm{PRED}} \mathrm{UP}$ with $D^{\text {ExpCap } U P ~ a n d ~} D^{\text {CcaHca } U P, ~ w h e r e ~} D^{\text {ExpCap }}\left(D^{\text {CcaHca }}\right)$ denotes an indicator variable that equals 1 in year $t+1$ and $t+2$ if the firm has adopted a change from expensing to capitalisation (CCA to HCA change) in year $t$, the results are similar (not reported). These results support hypothesis 6 .

The positive sign of the coefficient on $D^{\mathrm{EBEI}} D^{\mathrm{AC}} \mathrm{UP}(0.1223, \mathrm{t}=1.72, \mathrm{p}<0.10)$ suggests weakly that EBEI changes, in comparison with non-EBEI changes, strengthen the relation between predictability and accuracy, unless the accounting change is previously disclosed. The marginally negative coefficient on $D^{\mathrm{EBEI}} D^{\mathrm{DISC}} \mathrm{UP}(-0.1650, \mathrm{t}=-1.82, \mathrm{p}<0.10)$ suggests that prior disclosure results in a situation in which the association between predictability and accuracy almost fully disappears. These coefficients indicate that analysts' forecasting superiority over mechanical prediction models decreases after EBEI changes. An explanation for this is that after these accounting changes, the change effect becomes a distinctive factor in determining forecast accuracy, both for analysts and mechanical prediction models, which decreases analysts' forecasting superiority. However, when EBEI changes are previously 
disclosed, analysts' information advantage over mechanical prediction models is significant, resulting in an increase in analysts' forecasting superiority. Although the previous analyses indicated that the accounting change effect on average does not negatively affect analysts' forecast accuracy, these results suggest that the change effect can be an important determinant of the composition of analysts' forecast error.

\section{CONCLUSIONS}

This study assesses the influence of discretionary accounting changes on analysts' forecast errors in the Netherlands. The accounting information set that analysts following Dutch companies access after an accounting change is less informative than before the change, since Dutch companies rarely restate figures for prior years in the historical summary. Despite this, I find that accounting changes with a material influence on earnings before extraordinary items (EBEI changes) do not impair forecast accuracy in the change year or in the years after the change. Additional tests indicate that forecast accuracy improvements in the presence of EBEI changes can be attributed to decreases in the level of information asymmetry. This suggests that EBEI changes are on average part of an improvement in the company's information environment.

The empirical analysis further reveals that the importance of the earnings predictability measure in explaining consensus forecast errors varies with management's accounting choice. This suggests that analysts forecasting superiority over mechanical prediction models differs when accounting systems differ. Furthermore, the fact that accounting changes to historical cost accounting and capitalisation of costs causes analysts' forecast errors to be not only more accurate but also less correlated with forecast errors of mechanical earnings prediction models, indicates that these accounting methods offer better information to important users 
of accounting information.

\begin{abstract}
Notes
${ }^{1}$ Brown et al. (1985) suggest that short-term forecasts incorporate transitory earnings components, after finding that long-term forecasts are more valuation relevant than short-term forecasts. Bandyopadhyay et al. (1995) also observe a difference in valuation relevance between long-term forecasts and
\end{abstract} short-term forecasts.

${ }^{2}$ The five percent rule is a materiality criterion that is often used in Dutch guidelines for financial reporting. I classify accounting changes with a material effect on both earnings before extraordinary items and net profit as EBEI-changes.

${ }^{3}$ I realise that accounting changes can be disclosed in reports other than prior annual reports. However, excluding interim disclosure of changes ensures that all individual one-year-horizon earnings forecasts can be assumed to be affected by prior disclosure. Using only this type of disclosure may understate the impact of prior disclosure, i.e. reduce the significance of the empirical results.

${ }^{4}$ For example, Basu et al. (1998) provide evidence that the use of more accrual basis accounting than cash basis accounting results in higher earnings predictability. They measure earnings predictability on the basis of earnings variability and analysts' earnings forecast errors.

${ }^{5}$ The Financial Accounting Policy Committee of the Association for Investment Management and Research also expressed concerns over the effect of current cost accounting on the volatility of reported earnings (AIMR, 1993, p. 43). A closer examination of the changes from current cost accounting to historical cost accounting used in this study shows that it is reasonable to assume that these changes smooth reported earnings. In fifty percent of the cases I could obtain both earnings based on current cost accounting and earnings based on historical cost accounting of change firms from 1988 up to the change year. It appears from these data that absolute changes in 'current cost' earnings are significantly higher than absolute changes in 'historical cost' earnings. The mean difference equals 1.9 percent of lagged earnings (Wilcoxon z-value $=3.219, \mathrm{p}<0.01$ ), and 6.0 percent of changes in 'historical cost' earnings.

${ }^{6}$ Some studies indicate that small firms prefer capitalisation, whereas large firms prefer expensing (see e.g. Trombley, 1989). As a consequence the relationship between capitalisation versus expensing and forecast accuracy can be dependent on the relationship between size and accuracy. Financial analysts' earnings forecasts are generally found to be more accurate for larger firms (see e.g. Lys and Soo, 1995; Lang and Lundholm, 1996). This would imply that changes from capitalisation to expensing lead to higher forecast accuracy. Since it is unlikely that changes from expensing to capitalisation are adopted by large firms becoming small firms, these changes are not subject to size effects and probably 
more useful when studying whether the choice between capitalisation and expensing affects forecast accuracy.

${ }^{7}$ For instance, the Shapiro-Wilk statistic of differences between absolute initial one-year-horizon forecast errors in change years and in the first year prior to the change year equals $0.5022(\mathrm{p}<0.01)$.

${ }^{8}$ Due to limitations of the data set matched pairs are formed by two forecasts of one broker, which in theory does not necessarily coincide with two forecasts of one analyst. Analyst codes are available for 68.6 percent of the observations. Examinations of this subset reveal that in 5.1 percent of all firmbroker-year-horizon observations different analysts of one broker submitted earnings forecasts for the same firm, year and horizon. In 8.5 percent of these cases submissions were not fully sequential, that is, not likely to be caused by succession. Therefore, it is reasonable to assume that a vast majority of the firms is followed by only one analyst per broker

${ }^{9}$ The data used in this study appear to be severely skewed. For instance, the skewness coefficient of differences between absolute initial forecast errors in change years and in the first year prior to the change equals $8.9846(\mathrm{p}<0.01)$, the skewness coefficient of differences between absolute initial forecast errors in the first year after the change and in the first year before the change equals $3.5139(\mathrm{p}<0.01)$. However, I recalculated the Wilcoxon signed ranks when using a bootstrapping method. This indicated that the bootstrap means are not significantly different from the reported signed ranks.

${ }^{10}$ Furthermore, when using prior period forecast errors as the benchmark, the question presents itself whether lifecycles influence the results. That is, are firms becoming more stable over time and does this explain the change in accounting principles? It can be expected that the influence of lifecycles is rather limited, since the firms that are listed on the Amsterdam Stock Exchange are to a large extent mature firms. Moreover, the adoption of accounting changes which are studied in this paper was not restricted to the smaller firms.

${ }^{11}$ I divide the firms into eleven categories according to the level of analyst following in the change year. I expect that the firms which are in the same categories, have comparable information environments and that changes in forecast accuracy through the years are comparable for these firms.

${ }^{12}$ Although usually earnings changes are regressed on abnormal stock returns, it has been proven that earnings levels should also be associated with abnormal stock returns (see, for example, Easton and Harris, 1991; Ohlson and Shroff, 1992; Strong and Walker, 1993). Furthermore, I expect that total returns exhibit stronger correlation with earnings than abnormal returns, since problems with estimating normal returns may induce additional error (see also Beaver et al., 1987).

${ }^{13}$ Beaver et al. (1987) show that when regressing changes in stock prices on earnings it makes little difference whether stock returns are inclusive or exclusive of dividends. This result most likely applies to listed companies in the Netherlands, since, in correspondence with US companies, dividends paid out by Dutch companies are relatively small. Stock returns are adjusted for stock splits and stock 
dividends.

${ }^{14}$ The mean unpredictability rank of firms adopting CCA to HCA changes is significantly lower in the two years after the adoption than in the two years before the adoption (the difference equals -0.5155 , $\mathrm{t}=-2.16, \mathrm{p}<0.05)$. The mean rank of firms adopting changes from expensing to capitalisation is not significantly lower (the difference equals $-0.1675, \mathrm{t}=-0.48$ ).

${ }^{15} \mathrm{An}$ example of a study on earnings forecasting that also makes use of bootstrap regression is that of Kross et al. (1990).

${ }^{16}$ White's tests indicate that in the error regressions the data are heteroskedastic (Chi-square $=42.692$, df $10, \mathrm{p}<0.01)$.

\section{References}

AIMR (1993), Financial Reporting in the 1990s and Beyond (Association for Investment Management and Research, Charlottesville, VA).

Bandyopadhyay, S. P., L. D. Brown and G. D. Richardson (1995), 'Analysts' Use of Earnings Forecasts in Predicting Stock Returns: Forecast Horizon Effects', International Journal of Forecasting, Vol. 11, pp. 429-445.

Bannister, J. W. and H. A. Newman (1996), 'Accrual Usage to Manage Earnings Toward Financial Analysts' Forecasts', Review of Quantitative Finance and Accounting, Vol. 7, pp. 259-278.

Bartov, E. and G. M. Bodnar (1996), 'Alternative Accounting Methods, Information Asymmetry and Liquidity: Theory and Evidence', The Accounting Review, Vol. 71 (July), pp. 397-418.

Basu, S., L. Hwang and C.-L. Jan (1998), 'International Variation in Accounting Measurement Rules and Analysts' Earnings Forecast Errors', Journal of Business Finance 83 Accounting, Vol. 25, pp. 1207-1247.

Beaver, W. H., R. A. Lambert and S. G. Ryan (1987), 'The Information Content of Security Prices: A Second Look', Journal of Accounting and Economics, Vol. 9, pp. 139-157.

Brown, L. D. (1983), 'Accounting Changes and the Accuracy of Analysts' Earnings Forecasts', Journal of Accounting Research, Vol. 21 (Autumn), pp. 432-443.

Brown, L. D., G. D. Richardson and S. J. Schwager (1987), 'An Information Interpretation of Financial Analyst Superiority in Forecasting Earnings', Journal of Accounting Research, Vol. 25 (Spring), pp. 49-67.

Brown, P., G. Foster and E. Noreen (1985), Security Analyst Multi-Year Earnings Forecasts and the Capital Markets (Studies in Accounting Research, No. 21, American Accounting Association, Sarasota). 
Das, S., C. B. Levine and K. Sivaramakrishnan (1998), 'Earnings Predictability and Bias in Analysts' Earnings Forecasts', The Accounting Review, Vol. 73, pp. 277-294.

Davidson, R. and J. G. MacKinnon (1993), Estimation and Inference in Econometrics (Oxford University Press, New York, NY).

Degeorge, F., J. Patel and R. Zeckhauser (1999), 'Earnings Management to Exceed Thresholds', The Journal of Business, Vol. 72, pp. 1-34.

Easton, P. D. and T. S. Harris (1991), 'Earnings as an Explanatory Variable for Returns', Journal of Accounting Research, Vol. 29 (Spring), pp. 19-36.

Elliott, J. A. and D. R. Philbrick (1990), 'Accounting Changes and Earnings Predictability', The Accounting Review, Vol. 65 (January), pp. 157-174.

Healy, P. M. (1985), 'The Effect of Bonus Schemes on Accounting Decisions', Journal of Accounting and Economics, Vol. 7, pp. 85-107.

Krishnaswami, S. and V. Subramaniam (1999), 'Information Asymmetry, Valuation, and the Corporate Spin-Off Decision', Journal of Financial Economics, Vol. 53, pp. 73-112.

Kross, W., B. Ro and D. Schroeder (1990), 'Earnings Expectations: The Analysts' Information Advantage', The Accounting Review, Vol. 65 (April), pp. 461-476.

Lang, M. H. and R. J. Lundholm (1996), 'Corporate Disclosure Policy and Analyst Behavior', The Accounting Review, Vol. 71 (October), pp. 467-492.

Lys, T. and L. G. Soo (1995), 'Analysts' Forecast Precision as a Response to Competition', Journal of Accounting, Auditing and Finance, Vol. 10, pp. 751-765.

Mest, D. P. and E. Plummer (1999), 'Transitory and Persistent Earnings Components as Reflected in Analysts' Short-Term and Long-Term Earnings Forecasts: Evidence from a Nonlinear Model', International Journal of Forecasting, Vol. 15, pp. 291-308.

Ohlson, J. A. and P. K. Shroff (1992), 'Changes versus Levels in Earnings as Explanatory Variables for Returns: Some Theoretical Considerations', Journal of Accounting Research, Vol. 30 (Autumn), pp. 210-226.

Schattke, R. and R. Vergoossen (1996), 'Barriers to Interpretation - A Case Study of Philips Electronics NV', Accounting and Business Research, Vol. 27, pp. 71-84.

Strong, N. and M. Walker (1993), 'The Explanatory Power of Earnings for Stock Returns', The Accounting Review, Vol. 68 (April), pp. 385-399.

Sweeney, A. P. (1994), 'Debt-Covenant Violations and Managers' Accounting Responses', Journal of Accounting and Economics, Vol. 17, pp. 281-308.

Trombley, M. A. (1989), 'Accounting Method Choice in the Software Industry: Characteristics of Firms Electing Early Adoption of SFAS No. 86', The Accounting Review, Vol. 64, pp. 529-538.

Vergoossen, R. G. (1997), 'Changes in Accounting Policies and Investment Analysts' Fixation on Accounting Figures', Accounting, Organizations and Society, Vol. 22 (August), pp. 589-607. 
Table 1:

Description and distribution of accounting changes adopted by

Dutch companies from 1988 to 1996

\begin{tabular}{|c|c|c|c|c|c|c|c|c|c|c|}
\hline Type of accounting change & 88 & 89 & 90 & 91 & 92 & 93 & 94 & 95 & 96 & Total \\
\hline \multicolumn{11}{|c|}{ Panel A: Description and distribution of accounting changes } \\
\hline Revenue recognition & 7 & 5 & 4 & 1 & 2 & 3 & 3 & 3 & 1 & 29 \\
\hline Current cost to historical cost & 2 & 1 & 1 & 4 & 3 & 2 & 1 & 3 & 5 & 22 \\
\hline Provisions & 4 & 2 & 1 & & 4 & 2 & & 4 & 1 & 18 \\
\hline Capitalisation to expensing & 1 & 3 & 3 & & 5 & 1 & & & & 13 \\
\hline expensing to capitalisation & 1 & 2 & 3 & & 2 & 1 & & 1 & 2 & 12 \\
\hline Cost recognition & 2 & 1 & 2 & 2 & & 1 & 1 & 1 & & 10 \\
\hline Miscellaneous asset valuation principles & & 1 & 1 & 1 & 2 & 1 & & 1 & 1 & 8 \\
\hline Foreign currency translation & & 1 & 2 & & & & & 1 & 1 & 5 \\
\hline Valuation of participations & & 1 & 2 & & & & & 1 & 1 & 5 \\
\hline Historical cost to current cost & & & & & 1 & & & 2 & & 3 \\
\hline Miscellaneous & & & & & & & & & & 0 \\
\hline EBEI changes & 14 & 13 & 10 & 3 & 13 & 6 & 5 & 8 & 8 & 80 \\
\hline Non-EBEI changes & 3 & 4 & 9 & 5 & 6 & 5 & 0 & 9 & 4 & 45 \\
\hline Total & 17 & 17 & 19 & 8 & 19 & 11 & 5 & 17 & 12 & 125 \\
\hline
\end{tabular}

Panel B: Number of accounting changes included

All accounting changes

Preceded or followed by other change 10

No forecast data available $\quad 13$

No price data available $\quad 23$

$\begin{array}{ll}\text { Total included changes } & 79\end{array}$

Less: more than one change per year $\quad r 13$

Total included firms $\quad 56$

Data Source: The accounting change data come from the annual reports of 243 companies listed on the Amsterdam Stock Exchange during 1988 to 1996 for one or more years. Stock prices are from Datastream, analysts' earnings forecast data are from I/B/E/S. 
Table 2:

Descriptive statistics of analysts' forecast errors, forecast horizon and analyst following in the five years surrounding the accounting change

\begin{tabular}{|c|c|c|c|c|c|c|c|c|}
\hline Variable $^{\mathrm{a}}$ & $\begin{array}{l}\text { Years of } \\
\text { observation }^{\mathrm{b}}\end{array}$ & \#obs. ${ }^{\mathrm{c}}$ & Mean & $S D$ & Skewness & Q3 & Median & $Q 1$ \\
\hline Individual forecast & $\mathrm{t}-2$ & 686 & 0.0420 & 0.1162 & 4.0985 & 0.0190 & 0.0071 & 0.0023 \\
\hline \multirow[t]{4}{*}{ error } & $\mathrm{t}-1$ & 934 & 0.0176 & 0.0320 & 4.5440 & 0.0193 & 0.0078 & 0.0026 \\
\hline & $\mathrm{t}$ & 1,079 & 0.0281 & 0.0692 & 8.3306 & 0.0183 & 0.0068 & 0.0023 \\
\hline & $t+1$ & 992 & 0.0462 & 0.1135 & 3.6517 & 0.0207 & 0.0051 & 0.0022 \\
\hline & $t+2$ & 852 & 0.0176 & 0.0346 & 5.7270 & 0.0189 & 0.0063 & 0.0019 \\
\hline \multirow[t]{5}{*}{ Forecast horizon } & $\mathrm{t}-2$ & 686 & 173.05 & 113.18 & -0.60 & 250 & 203 & 104 \\
\hline & $\mathrm{t}-1$ & 934 & 175.02 & 119.63 & -0.27 & 253 & 200 & 105 \\
\hline & $\mathrm{t}$ & 1,079 & 172.77 & 109.56 & -0.88 & 254 & 204 & 108 \\
\hline & $t+1$ & 992 & 183.29 & 104.25 & -0.99 & 258 & 220 & 115 \\
\hline & $t+2$ & 852 & 169.83 & 106.92 & -0.79 & 251 & 197 & 106 \\
\hline \multirow[t]{5}{*}{ Analyst following } & $\mathrm{t}-2$ & 686 & 22.18 & 9.16 & -0.02 & 29 & 21 & 16 \\
\hline & $\mathrm{t}-1$ & 934 & 24.55 & 9.84 & -0.25 & 33 & 23 & 18 \\
\hline & $\mathrm{t}$ & 1,079 & 25.78 & 10.21 & -0.58 & 33 & 27 & 20 \\
\hline & $t+1$ & 992 & 28.04 & 10.72 & -0.75 & 37 & 31 & 22 \\
\hline & $t+2$ & 852 & 30.68 & 10.19 & -1.15 & 38 & 34 & 25 \\
\hline
\end{tabular}

a The variables have the following definitions:

Forecast horizion $=$ The number of days between the submission of the individual earnings forecast and the fiscal year end.

Analyst following $=$ The number of analysts that has submitted at least one earnings forecast for the same company in the same year.

b Year $t$ denotes the year in which the accounting change is adopted.

c Descriptive statistics are based on all available earnings forecasts for the companies that are included in my sample. 
Table 3:

Comparison of analysts' earnings forecast accuracy in the change year and years after the change with forecast accuracy in the year prior to the change

\begin{tabular}{|c|c|c|c|c|}
\hline & \#obs & $\begin{array}{l}\text { perc. } \\
\text { change } \\
\text { firms } \\
\end{array}$ & $\begin{array}{c}z \text {-statistic } \\
\text { Rank Sum change firms }> \\
\text { Rank Sum control group } \\
\end{array}$ & $\begin{array}{c}\text {-statistic } \\
\text { Rank Sum EBEI> } \\
\text { Rank Sum non-EBEI }\end{array}$ \\
\hline \multicolumn{5}{|c|}{ Panel A: Change year vs. year before change $^{\mathrm{a}}$} \\
\hline EBEI changes ${ }^{b}$ & 456 & $\begin{array}{l}45.8 \% \\
(-1.62)\end{array}$ & $-2.20^{\ddagger}$ & $-3.51^{\dagger}$ \\
\hline Non-EBEI changes & 317 & $\begin{array}{l}57.4 \% \\
(3.71)^{\dagger}\end{array}$ & $1.96^{\ddagger}$ & \\
\hline \multicolumn{5}{|c|}{ Panel B: First year after vs. year before change } \\
\hline EBEI changes & 329 & $\begin{array}{l}38.9 \% \\
(-2.72)^{\dagger}\end{array}$ & -0.01 & $-3.14^{\dagger}$ \\
\hline Non-EBEI changes & 249 & $\begin{array}{l}55.0 \% \\
(2.24)^{\ddagger}\end{array}$ & $2.28^{\ddagger}$ & \\
\hline \multicolumn{5}{|c|}{ Panel C: Second year after vs. year before change } \\
\hline EBEI changes & 233 & $\begin{array}{l}30.9 \% \\
(-5.73)^{\dagger}\end{array}$ & -1.24 & $-4.59^{\dagger}$ \\
\hline Non-EBEI changes & 146 & $\begin{array}{l}56.2 \% \\
(1.51)\end{array}$ & 1.14 & \\
\hline
\end{tabular}

${ }^{a}$ Panel A, panel B and panel C compare forecast errors in the year prior to the change year with forecast errors in the change year, first year after the change year and second year after the change year, respectively.

\footnotetext{
$\mathrm{EBEI}=\quad$ Accounting changes that have a material influence (of 5 percent or more) on earnings before extraordinary items.

Non-EBEI $=$ Accounting changes that have a material influence (of 5 percent or more) on net earnings or equity but do not affect earnings before extraordinary items materially.

c Percentage of cases in which analysts' individual forecast errors in change years are greater than their forecast errors in prior years. Z-statistics of Wilcoxon signed rank tests on differences in forecast errors are in parentheses.

${ }^{\mathrm{d}}$ Z-statistics of Wilcoxon rank sum tests, which indicate whether the rank sum of differences in forecast error in the change firm sample is significantly greater than the rank sum of differences in the control sample. These statistics are based on the mean rank sum of 500 control samples.

e Z-statistics of Wilcoxon rank sum tests, which indicate whether the rank sum of differences in forecast error from the firms adopting EBEI changes is significantly greater than the rank sum of differences from the firms adopting non-EBEI changes.

$\dagger, \ddagger, *$ Significant at the two-tailed $0.01,0.05$ and 0.10 alpha level, respectively.
} 
Table 4:

The influence of previously disclosed versus non-disclosed accounting changes on earnings forecast accuracy

\begin{tabular}{|c|c|c|c|c|}
\hline & \#obs & $\begin{array}{l}\text { perc. } \\
\text { change } \\
\text { firms }^{\mathrm{b}}\end{array}$ & $\begin{array}{c}\text {-statistic } \\
\text { Rank Sum change firms }> \\
\text { Rank Sum control group } \\
\end{array}$ & \begin{tabular}{l}
\multicolumn{1}{c}{$z$-statistic } \\
Rank Sum PD> \\
Rank Sum NPD \\
\end{tabular} \\
\hline \multicolumn{5}{|c|}{ Panel A: EBEI changes } \\
\hline Prior disclosure ${ }^{\mathrm{a}}$ & 159 & $\begin{array}{l}35.2 \% \\
(-6.04)^{\dagger}\end{array}$ & $-2.35^{\ddagger}$ & \multirow[t]{2}{*}{$-3.76^{\dagger}$} \\
\hline No prior disclosure & 297 & $\begin{array}{l}51.5 \% \\
(1.23)\end{array}$ & -1.06 & \\
\hline \multicolumn{5}{|c|}{ Panel B: Non-EBEI changes } \\
\hline Prior disclosure & 157 & $\begin{array}{l}61.1 \% \\
(3.75)^{\dagger}\end{array}$ & $3.65^{\dagger}$ & \multirow[t]{2}{*}{$2.10^{\ddagger}$} \\
\hline No prior disclosure & 160 & $\begin{array}{l}53.8 \% \\
(1.44)\end{array}$ & -0.95 & \\
\hline
\end{tabular}

a Prior disclosure $(\mathrm{PD})=\quad$ Management's intention to change accounting procedures has been disclosed in the annual report of the first year No prior disclosure $(\mathrm{NPD})=\begin{aligned} & \text { prior to the change year. } \\ & \text { Management's intention to change accounting procedures }\end{aligned}$ has not been disclosed in the annual report of the first year prior to the change year.

b Percentage of cases in which analysts' individual forecast errors in change years are greater than their forecast errors in prior years. Z-statistics of Wilcoxon signed rank tests on differences in forecast errors are in parentheses.

${ }^{c}$ Z-statistics of Wilcoxon rank sum tests, which indicate whether the rank sum of differences in forecast error in the change firm sample is significantly greater than the rank sum of differences in the control sample. These statistics are based on the mean rank sum of 500 control samples.

d Z-statistics of Wilcoxon rank sum tests, which indicate whether the rank sum of differences in forecast error from the PD-firms is significantly greater than the rank sum of differences from the NPD-firms.

$\dagger, \ddagger, *$ Significant at the two-tailed $0.01,0.05$ and 0.10 alpha level, respectively. 
Table 5:

The influence of changes in analyst following, changes in forecast horizon and changes in stock return volatility on signed ranks. Dependent variable is the signed ranks of changes in analysts' individual forecast error ${ }^{\mathrm{a}}$

\begin{tabular}{|c|c|c|c|c|c|c|c|}
\hline & \#obs & Model & Intercept & $\Delta$ Follow & $\Delta$ Horizon & $D^{S T D}$ & $\operatorname{adj.} R^{2}$ \\
\hline \multicolumn{8}{|c|}{ Panel A: Change year vs. year before change } \\
\hline \multirow[t]{2}{*}{ EBEI changes } & 456 & Model 1 & $\begin{array}{r}-30.2765 \\
(-2.23)^{\ddagger}\end{array}$ & $\begin{array}{r}-0.9555 \\
(-0.33)\end{array}$ & $\begin{array}{c}0.3836 \\
(4.32)^{\dagger}\end{array}$ & - & 0.0396 \\
\hline & & Model 2 & $\begin{array}{r}1.5537 \\
(0.07)\end{array}$ & $\begin{array}{r}-3.7318 \\
(-1.16)\end{array}$ & $\begin{array}{c}0.3705 \\
(4.17)^{\dagger}\end{array}$ & $\begin{array}{r}-50.5757 \\
(-1.91)^{*}\end{array}$ & 0.0494 \\
\hline \multirow[t]{2}{*}{ non-EBEI changes } & 317 & Model 1 & $\begin{array}{r}4.5638 \\
(0.48)\end{array}$ & $\begin{array}{r}14.7993 \\
(6.33)^{\dagger}\end{array}$ & $\begin{array}{c}0.1488 \\
(2.07)^{\ddagger}\end{array}$ & ; & 0.0386 \\
\hline & & Model 2 & $\begin{array}{r}78.3994 \\
(6.05)^{\dagger}\end{array}$ & $\begin{array}{r}10.2660 \\
(4.49)^{\dagger}\end{array}$ & $\begin{array}{c}0.1528 \\
(2.22)^{\dagger}\end{array}$ & $\begin{array}{r}-138.4266 \\
(-7.59)^{\ddagger}\end{array}$ & 0.2790 \\
\hline \multicolumn{8}{|c|}{ Panel B: First year after vs. year before change } \\
\hline \multirow[t]{2}{*}{ EBEI changes } & 329 & Model 1 & $\begin{array}{r}-13.1781 \\
(-0.89)\end{array}$ & $\begin{array}{l}-4.6883 \\
(-2.01)^{\ddagger}\end{array}$ & $\begin{array}{c}0.2290 \\
(3.15)^{\dagger}\end{array}$ & & 0.0477 \\
\hline & & Model 2 & $\begin{array}{r}19.5587 \\
(1.06)\end{array}$ & $\begin{array}{c}-6.8285 \\
(-2.97)^{\dagger}\end{array}$ & $\begin{array}{c}0.2088 \\
(2.80)^{\dagger}\end{array}$ & $\begin{array}{r}-61.4809 \\
(-3.14)^{\dagger}\end{array}$ & 0.0707 \\
\hline \multirow[t]{2}{*}{ non-EBEI changes } & 249 & Model 1 & $\begin{array}{r}-17.5844 \\
(-1.26)\end{array}$ & $\begin{array}{c}6.1506 \\
(3.17)^{\dagger}\end{array}$ & $\begin{array}{c}0.3152 \\
(5.67)^{\dagger}\end{array}$ & & 0.1459 \\
\hline & & Model 2 & $\begin{array}{r}-11.5934 \\
(-0.82)\end{array}$ & $\begin{array}{c}6.8082 \\
(3.47)^{\dagger}\end{array}$ & $\begin{array}{c}0.3081 \\
(5.52)^{\dagger}\end{array}$ & $\begin{array}{r}-27.6038 \\
(-1.44)\end{array}$ & 0.1570 \\
\hline
\end{tabular}

${ }^{\text {a }}$ Independent variables are:

$\Delta \mathrm{FOLLOW}=$ Change in analyst following, defined as the company-specific number of analysts that has submitted at least one earnings forecast for the same company in the same year.

$\Delta$ HORIZON $=$ Change in forecast horizon, defined as the forecast-specific number of days between the I/B/E/S forecast submission date and the fiscal year end.

$D^{\mathrm{STD}}=\quad$ Indicator variable that equals one if the standard deviation of abnormal stock returns has decreased after the publication of the annual report of year $t-1$. 


\section{Table 6:}

The influence of changes from current cost accounting to historical cost accounting and changes from expensing to capitalisation on analysts' forecast accuracy

\begin{tabular}{|c|c|c|c|c|}
\hline & \#obs & $\begin{array}{l}\text { perc. } \\
\text { change } \\
\text { firms }^{\mathrm{b}}\end{array}$ & $\begin{array}{c}z \text {-statistic } \\
\text { Rank Sum change firms }> \\
\text { Rank Sum control group }\end{array}$ & $\begin{array}{c}\text { z-statistic } \\
\text { Rank Sum EPI> } \\
\text { Rank Sum Other }\end{array}$ \\
\hline \multicolumn{5}{|c|}{ Panel A: EBEI changes } \\
\hline $\mathrm{CCA}$ to $\mathrm{HCA}^{\mathrm{a}}$ & 190 & $\begin{array}{l}29.5 \% \\
(-8.30)^{\dagger}\end{array}$ & $-11.64^{\dagger}$ & $-4.98^{\dagger}$ \\
\hline Exp to Cap & 77 & $\begin{array}{l}32.5 \% \\
(-2.18)^{\ddagger}\end{array}$ & $4.33^{\dagger}$ & 0.09 \\
\hline Other changes & 295 & $\begin{array}{l}40.4 \% \\
(-1.23)\end{array}$ & $2.35^{\ddagger}$ & \\
\hline \multicolumn{5}{|c|}{ Panel B: Non-EBEI changes } \\
\hline $\mathrm{CCA}$ to $\mathrm{HCA}$ & 148 & $\begin{array}{l}39.9 \% \\
(-3.69)^{\dagger}\end{array}$ & $-2.65^{\dagger}$ & $-6.70^{\dagger}$ \\
\hline Exp to Cap & 96 & $\begin{array}{l}60.4 \% \\
(2.33)^{\ddagger}\end{array}$ & $1.97^{\ddagger}$ & $-3.96^{\dagger}$ \\
\hline Other changes & 151 & $\begin{array}{l}67.5 \% \\
(6.93)^{\dagger}\end{array}$ & $4.65^{\dagger}$ & \\
\hline
\end{tabular}

CCA-HCA $=$ Changes from current cost accounting to historical cost accounting. Exp to Cap $=$ Changes from expensing to capitalisation.

b Percentage of cases in which analysts' individual forecast errors in the two years after the accounting change are greater than their forecast errors in prior years. Z-statistics of Wilcoxon signed rank tests on differences in forecast errors are in parentheses.

c Z-statistics of Wilcoxon rank sum tests, which indicate whether the rank sum of differences in forecast error in the change firm sample is significantly greater than the rank sum of differences in the control sample. These statistics are based on the mean rank sum of 500 control samples.

d Z-statistics of Wilcoxon rank sum tests, which indicate whether the rank sum of differences in forecast error from the firms adopting CCA to HCA changes or Exp to Cap changes (earnings predictability improving changes (EPI)) is significantly greater than the rank sum of differences from the firms adopting all other accounting changes.

$\dagger, \ddagger, *$ Significant at the two-tailed $0.01,0.05$ and 0.10 alpha level, respectively. 
Table 7:

Regression analysis of forecast errors and earnings predictability measures. Dependent variable is analysts' consensus forecast error ${ }^{a}$

\begin{tabular}{|c|c|c|c|c|c|c|}
\hline \multirow[b]{2}{*}{ Independent variable } & \multicolumn{3}{|c|}{ Model (1) } & \multicolumn{3}{|c|}{ Model (2) } \\
\hline & Mean & t-value & $p$-value & Mean & t-value & $p$-value \\
\hline Intercept & 0.0338 & 3.23 & 0.001 & 0.0228 & 1.66 & 0.098 \\
\hline UP & 0.0526 & 3.06 & 0.002 & 0.0526 & 3.08 & 0.002 \\
\hline FOLLOW & -0.0002 & -0.28 & 0.780 & -0.0001 & -0.10 & 0.920 \\
\hline SIZE & 0.0006 & 1.50 & 0.135 & 0.0006 & 1.27 & 0.205 \\
\hline$D^{\mathrm{AC}} \mathrm{UP}$ & 0.0775 & 1.30 & 0.195 & -0.0171 & -0.61 & 0.542 \\
\hline$D^{\mathrm{DISC}} \mathrm{UP}$ & -0.1059 & -1.72 & 0.087 & 0.0088 & 0.20 & 0.842 \\
\hline$D^{\text {AFTER }} U P$ & 0.0100 & 0.44 & 0.660 & -0.0031 & -0.13 & 0.897 \\
\hline$D^{\text {PRED }} \mathrm{UP}$ & -0.0549 & -3.48 & 0.001 & -0.0532 & -3.45 & 0.001 \\
\hline$D^{\mathrm{EBEI}} D^{\mathrm{AC}} \mathrm{UP}$ & - & - & - & 0.1223 & 1.72 & 0.087 \\
\hline$D^{\mathrm{EBEI}} D^{\mathrm{DISC}} \mathrm{UP}$ & - & - & - & -0.1650 & -1.82 & 0.070 \\
\hline$D^{\mathrm{EBEI}} D^{\mathrm{AFTER}} \mathrm{UP}$ & - & - & - & 0.0164 & 0.76 & 0.448 \\
\hline adj. $R^{2}$ & 0.4089 & & & 0.4396 & & \\
\hline \#obs. ${ }^{\mathrm{b}}$ & 260 & & & 260 & & \\
\hline
\end{tabular}

$\mathrm{UP}=\quad$ unpredictability measure based on a random walk model, an au-

FOLLOW $=$ toregressive model and a returns model

$=$ number of analysts that follows firm $i$ in year $t$

$\mathrm{SIZE}=\quad$ market value of common equity of firm $i$ at the fiscal year-end

$D^{\mathrm{AC}}=\quad$ indicator variable, equals 1 if firm $i$ adopts a material accounting

change in year $t$

$D^{\text {DISC }}=\quad$ indicator variable, equals 1 (in year $t$ ) if firm $i$ has disclosed the intention to change accounting procedures in the annual report of

$D^{\text {AFTER }}=\quad \begin{aligned} & \text { year } t-1 \\ & \text { indicator variable, equals } 1 \text { (in year } t) \text { if firm } i \text { has adopted an }\end{aligned}$

$D^{\mathrm{PRED}}=\quad \begin{aligned} & \text { accounting change in year } t-1 \text { or in year } t \text { - } 2 \\ & \text { indicator variable, equals } 1 \text { (in year } t) \text { if firm } i \text { has adopted changes }\end{aligned}$ from current cost accounting to historical cost accounting or changes

from expensing to capitalisation in year $t-1$ or in year $t$-2

$D^{\mathrm{EBEI}}=\quad$ indicator variable, equals 1 if firm $i$ has adopted an accounting change with a material effect on earnings before extraordinary items in the years $t-2, t-1, t, t+1$ or $t+2$

$\mathrm{b}$ The data used to estimate the regression are from two years prior to the accounting change, the change year and two years after the accounting change.

Number of observations:

Firm-year observations (66) times $5=\quad 330$

less: years before 1988 or after $1996=\quad 52$

less: not listed in one or more years $=\quad 4$

less: other accounting change in one or more years $=\quad 6$

less: no forecast data available in one or more years $=\quad 3$

less: no rank scores available $=\quad 5$

Total observations $=\quad 260$ 